\title{
THE CONFLATION OF ANNA MARIA MORDAUNT (d. 1771) AND ANNA MARIA MORDAUNT (1716/7-1803)
}

Research conducted during the routine process of investigating corrections submitted to the Oxford Dictionary of National Biography has identified a longstanding and widespread confusion between Anna Maria Mordaunt (d. 1771), a maid of honour to Queen Caroline and the dedicatee of Samuel Croxall's The Fair Circassian (1720), and her younger cousin Anna Maria Mordaunt (1716/7-1803).

The first of these two women was the daughter of Brigadier-General Lewis Mordaunt (1665-1713). Samuel Croxall dedicated The Fair Circassian (1720) to her 'in fulsomely amorous terms' which later literary critics have found rather distasteful. ${ }^{1}$ She served as Maid of Honour to Queen Caroline in the years 1727-1732. ${ }^{2}$ Following which she married the diplomat Stephen Poyntz (d. 1750) in February 1733. ${ }^{3}$ The younger and less illustrious Anna Maria Mordaunt (1716/7-1803) was the daughter of Rev. George Mordaunt (brother of afore mentioned Lewis). This second Anna Maria married Jonathan Shipley (1713-1788), later bishop of St Asaph, in $1743 .{ }^{4}$ She cannot have been the dedicatee of The Fair Circassian as she was only three or four years old in 1720 . Similarly, it seems highly unlikely that it was she who was a Maid of Honour to Queen Caroline, given that she would only have been 10 or 11 years old in 1727 . This branch of the Mordaunt family genealogy is given in detail in Burke's Peerage..$^{5}$

There has been a longstanding and widespread tendency to conflate these women, exporting details from the biography of the better known Anna Maria Poyntz, nee Mordaunt (d. 1771) - notably her 
position as a Maid of Honour - to populate the sparser biography of Anna Maria Shipley, nee Mordaunt (d. 1803). For modern examples see Michael J. Franklin's 'Orientalist Jones': Sir William Jones, Poet, Lawyer, and Linguist, 1746-1794 (2011) and Stewart Cooke's edition of The Additional Journals and Letters of Frances Burney $(2015) .{ }^{6}$ This confusion also finds its way into the ODNB. The article for Samuel Croxall misquotes the death date of the dedicatee of The Fair Circassian as 1803 (it should read 1771). ${ }^{7}$ Meanwhile, the article for Jonathan Shipley claims that his bride was 'celebrated in youth for her beauty and had served as a maid of honour to Queen Caroline'. ${ }^{8} \mathrm{H}$. L. Bennett's article on Shipley in the original DNB also identified this Anna Maria as 'one of Queen Caroline's maids of honour'. ${ }^{9}$

The source of this confusion seems most likely to have been Augustus John Cuthbert Hare's Memorials of a Quiet Life (1884), which describes Anna Maria Mordaunt (1716/7-1803) as 'daughter of the Honourable George Mordaunt, and niece of the famous Earl of Peterborough, who, in her youth, was celebrated as "the beautiful Miss Mordaunt", and was a Maid of Honour to Queen Caroline'. ${ }^{10}$ Though Hare was in fact a distant relative of this Anna Maria he appears to be wrong about her having been a Maid of Honour (see above). ${ }^{11}$ More speculatively I would suggest that Hare's allusion to Anna Maria's beauty being celebrated may be a reference to a short poem 'On Seeing the beautiful Miss Mordaunt's name on several stones under the Piazza in Sommersetgardens', which appeared in The London Magazine in June $1744 .{ }^{12}$

A further source of confusion regarding these women may be that they are both often described as 'nieces of the earl of Peterborough', especially in eighteenth century sources such as the Gentleman's Magazine. As their fathers (Lewis and George Mordaunt) were brothers, both of these women (who were cousins) were indeed 'nieces of the earl of Peterborough' (Charles Mordaunt brother of both Lewis and George), and this along with their names may have contributed to the conflation of their lives. 


\section{ANDERS INGRAM}

University of Oxford, Oxford Dictionary of National Biography

${ }^{1}$ James Sambrook, 'Croxall, Samuel (1688/9-1752)', ODNB.

${ }^{2}$ www.history.ac.uk/publications/office/queencaroline\#maid

${ }^{3}$ Philip Woodfine, 'Poyntz, Stephen (bap. 1685, d. 1750)', ODNB.

${ }^{4}$ Gentleman's Magazine (London, 1743), 1st ser., XIII, 498.

${ }^{5}$ Bernard Burke, A genealogical history of the dormant: abeyant, forfeited, and extinct peerages of the British empire (London, 1866), 380.

${ }^{6}$ Michael J. Franklin, 'Orientalist Jones': Sir William Jones, Poet, Lawyer, and Linguist, 1746-1794 (Oxford,

2011), 64; Frances Burney, The Additional Journals and Letters of Frances Burney, ed. Stewart Cooke (Oxford, 2015), I, $65 \mathrm{fn}$. 353. Both sources claim that the Anna Maria Mordaunt who married Jonathan Shipley had been Maid of Honour to the Queen.

7 James Sambrook, 'Croxall, Samuel (1688/9-1752)', ODNB.

${ }^{8}$ G. M. Ditchfield, 'Shipley, Jonathan (1713-1788)', ODNB.

${ }^{9}$ H. L. Bennett, Shipley, Jonathan (1714-1788), DNB (1897).

${ }^{10}$ Augustus J.C. Hare, Memorials of a Quiet Life (New York, 1884), 89.

${ }^{11}$ Augustus Hare was nephew of Julius Hare who in turn was grandson of this Anna Maria (d. 1803).

${ }^{12}$ The London Magazine: and monthly chronologer (London, [1744]), 303. The poem reads: 'Thy Beauties, Mordaunt, in each breast, Excite a gen'rous flame; Thy charms are wrote in ev'ry heart, On every stone thy name.' 